\title{
Pelatihan Perakitan Sistem Filterisasi Air Minum Skala Rumah Tangga
}

\author{
Muh Anshar, Rhiza S. Sadjad, Elyas Palantei, Zaenab, Dewiani \\ Departemen Elektro, Fakultas Teknik UNHAS \\ anshar@unhas.ac.id*
}

\begin{abstract}
Abstrak
Air bersih untuk kehidupan manusia merupakan elemen penting dalam kelangsungan hidup manusia (jika tersedia), luaran yang dicapai untuk tiap kelompok, ataupun dampak balik dari pelaksanaan kegiatan atau dampak sampingan kegiatana. Namun sampai saat ini masih ada daerah-daerah yang mengalami kesulitan akses air bersih yang notabene masih berkisar dalam daerah provinsi Sulawesi Selatan. Sebagai contoh pada daerah Kecamatan Mandai Kabupaten Maros Provinsi Sulawesi Selatan. Kegiatan pengabdian ini menawarkan solusi sistem penyediaan air bersih untuk umum yang nantinya diharapakan dapat meningkatkan kualitas air untuk konsumsi keseharian dari masyarakat mitra, dalam hal ini Desa Tellumpoccoe. Mekanisme yang digunakan mengawinkan teknologi pengadaan air melalui sumur pompa dan teknologi automasi yang mengefektifkan kinerja peralatan. Sistem ini juga akan mengintegrasikan sistem filterisasi guna meningkatkan kualitas air sehingga memenuhi standarisasi yang ditetapkan oleh Departemen Kesehatan Republik Indonesia. Sekitar 26 peserta latih mengikuti proses pelaksanaan kegiatan dengan tingkat penyerapan materi optimal melalui pengujian pelacakan kerusakan. Selain itu, data pendukung tingkat penyerapan materi juga diperoleh dari wawancara setelah kegiatan terkait materi pelatihan yang telah diberikan. Satu kelurga melaksanakan instalasi air bersih lebih jauh untuk konsumsi tingkat rumah tangga dan dari tim, diberikan pendampingan selama proses instalasi dan uji kelayakan konsumsi air hasil filterisasi. Luaran lainnya terbentknya tim teknis untuk penanggung jawab teknologi filterisasi air yang beranggotakan ke-26 peserta latih tersebut.
\end{abstract}

Kata Kunci: Pelatihan; Filterisasi; Air Bersih; Rumah Tangga; Salinitas.

\section{Pendahuluan}

Ketersediaan air bersih untuk kehidupan manusia merupakan elemen penting dalam kelangsungan hidup manusia. Hampir sebagian besar masyarakat pada kota-kota besar telah memiliki akses kepada sumber air bersih untuk layak konsumsi melalui perusahaan air yang ditunjuk oleh negara untuk mengelola ketersediaan sumber air bersih untuk tiap-tiap daerah, dalam hal ini Peruasahaan Daerah Air Minum (PDAM) Makassar.

Namun sampai saat ini masih ada daerah-daerah yang mengalami kesulitan akses air bersih yang notabene masih berkisar dalam daerah provinsi Sulawesi Selatan. Sebagai contoh pada daerah Kecamatan Mandai Kabupaten Maros Provinsi Sulawesi Selatan. Data statistik yang diperoleh dari Badan Statistik Kabupaten Maros menunjukkan bahwa jumlah penduduk untuk Kecamatan Mandai berjumlah 8.357 kepala rumah tangga dengan tingkat kepadatan penduduk sekitar 778,33 per km2 (BPS Maros, 2015), dimana untuk daerah ini, sumber air minum layak adalah air leding eceran/meteran, air hujan, dan pompa/sumur terlindung/mata air terlindung dengan jarak ke tempat penampungan kotoran/tinja >= $10 \mathrm{~m}$ (BPS Maros, 2015). Selain itu, untuk tahun 2014 terdapat kurang lebih 40.130 orang yang hidup dalam garis kemiskinan dengan persentase $11,93 \%$. Dengan tingkat kemiskinan yang relatif tinggi, dapat ditarik hubungan langsung terhadap kemampuan masyarakat secara umum dalam mengakses air leding eceran/meteran menjadi sangat minim dan pompa/sumur menjadi alternatif utama. Dari sumber alternatif ini, pengaruh zat-zat pencemar seperti bakteri, virus, deterjen, pestisida, logam berat, radioaktif, 
mineral anorganik, racun, dan lain sebagainya menjadi rentan mempengaruhi kualitas layak tidaknya air untuk dikonsumsi. Tidak adanya sistem filterisasi dari sumur-sumur galian tersebut menjadikan faktor penambah dalam meningkatnya dampak-dampak dari pengaruh zat-zat pencemar tersebut. Dampak lainnya adalah tingginya kadar garam yang terkandung di dalam sumur galian tersebut yang turut memperburuk kualitas air. Hal ini diperoleh setelah tim melakukan kunjungan langsung pada lokasi mitra dimana sumur galian menghasilkan kadar air dengan tingkat salinitas pada level tercium oleh indera manusia.

\section{Keterkaitan Kondisi dan Level Acuan Air Bersih}

Salah satu metode umum yang digunakan untuk mengetahui kandungan unsur mineral nonorganik yang ada dalam air adalah metode Total Dissolved Solids (TDS). Metode ini digunakan untuk mengetahui kandungan unsur mineral non-organik yang ada dalam air. Menurut Badan Kesehatan Dunia (WHO) standar kandungan TDS pada air minum yang termasuk dalam kategori sehat untuk diminum dan tidak membahayakan kesehatan yaitu antara 1 ppm sampai dengan 30 ppm. Jika kandungan TDS pada air yang kita minum melebihi 30 ppm maka sisanya tidak dapat diproses penguraiannya oleh organ vital manusia dan hal tersebut dapat menyebabkan kerusakan pada bagian organ vital. Guna memenuhi standar kandungan minimum yang tidak membahayakan tubuh, Pemerintah Republik Indonesia telah mengeluarkan Keputusan Menteri Kesehatan Republik Indonesia Nomor 1405/menkes/sk/xi/2002 tentang Persyaratan Kesehatan Lingkungan Kerja Perkantoran dan Industri. Dalam peraturan ini dicantumkan pengertian mengenai Air Bersih sebagai air yang dipergunakan untuk keperluan sehari-hari dan kualitasnya memenuhi persyaratan kesehatan air bersih sesuai dengan peraturan perundang-undangan yang berlaku dan dapat diminum apabila dimasak. Parameter kualitas air bersih yang ditetapkan dalam PERMENKES 416/1990 terdiri atas persyaratan fisik, persyaratan kimiawi, persyaratan mikrobiologis. Peraturan tentang persyaratan kualitas terkait air minum selanjutnya diatur pada Peraturan Menteri Kesehatan Republik Indonesia Nomor 429/Menkes/PER/IV/2010 (MENKES RI, 2010). Berikut ini adalah Persyaratan Air Layak Konsumsi:

\subsection{Persyaratan Fisik}

Persyaratan fisik yang harus dipenuhi pada air minum yaitu harus jernih, tidak berbau, tidak berasa dan tidak berwarna. Sementara suhunya sebaiknya sejuk dan tidak panas. Selain itu, air minum tidak menimbulkan endapan. Jika air yang kita konsumsi menyimpang dari hal ini, maka sangat mungkin air telah tercemar.

\subsection{Persyaratan Kimia}

Dari aspek kimiawi, bahan air minum tidak boleh mengandung partikel terlarut dalam jumlah tinggi serta logam berat (misalnya $\mathrm{Hg}, \mathrm{Ni}, \mathrm{Pb}, \mathrm{Zn}$, dan $\mathrm{Ag}$ ) ataupun zat beracun seperti senyawa hidrokarbon dan detergen. Ion logam berat dapat mendenaturasi protein, disamping itu logam berat dapat bereaksi dengan gugus fungsi lainnya dalam biomolekul. Karena sebagian akan tertimbun di berbagai organ terutama saluran cerna, hati dan ginjal, maka organ-organ inilah yang terutama dirusak.

\subsection{Persyaratan Mikrobiologis}

Bakteri patogen yang tercantum dalam Kepmenkes yaitu Escherichia Colli, Clostridium Perfringens, Salmonella. Bakteri patogen tersebut dapat membentuk toksin (racun) setelah periode laten yang singkat yaitu beberapa jam. Keberadaan bakteri Coliform (E. Coli tergolong 
jenis bakteri ini) yang banyak ditemui di kotoran manusia dan hewan menunjukkan kualitas sanitasi yang rendah dalam proses pengadaan air. Makin tinggi tingkat kontaminasi bakteri coliform, makin tinggi pula risiko kehadiran bakteri patogen, seperti bakteri Shigella (penyebab muntaber), S. Typhii (penyebab Typhus), Kolera, dan Disentri.

Selain kandungan dari air yang tersedia, data sebelumnya juga memperlihatkan tingkat salinitas yang tinggi, sehingga pemilihan solusi yang ditawarkan hendaknya mengakomodasi permasalahan tersebut. Berikut Gambar 1 memperlihatkan kawasan pada Desa Tellompoccoe yang diperkirakan mengandung kadar salinitas yang tinggi.

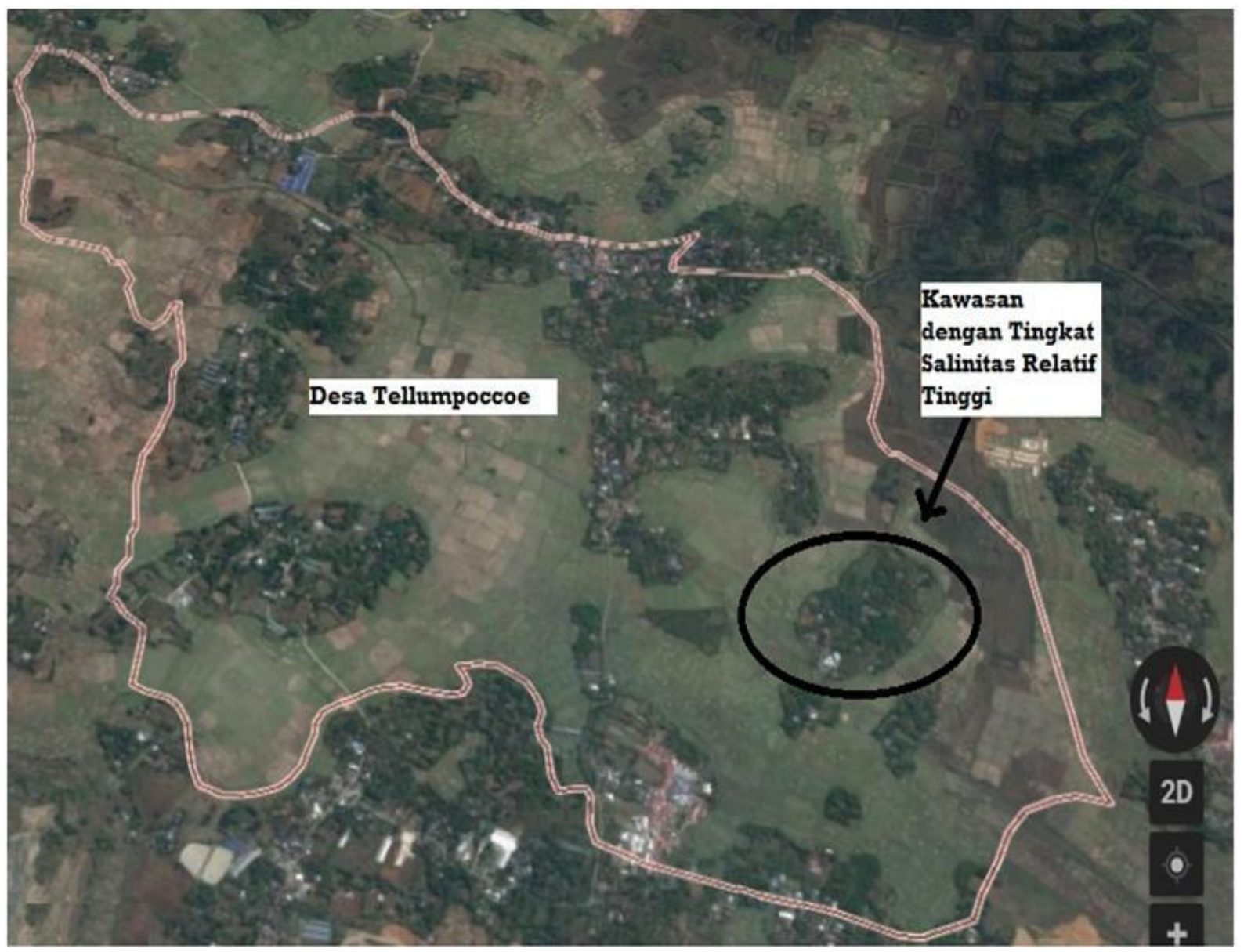

Gambar 1. Daerah dengan Tingkat Salinitas Tinggi

\section{Metode Untuk Menangani Permasalahan}

Sehubungan dengan permasalahan yang telah disebutkan di atas, maka kegiatan pengabdian ini menawarkan solusi sistem penyediaan air bersih untuk umum yang nantinya diharapakan dapat meningkatkan kualitas air untuk konsumsi keseharian dari masyarakat mitra, dalam hal ini Desa Tellumpoccoe. Mekanisme yang digunakan mengawinkan teknologi pengadaan air melalui sumur pompa dan teknologi automasi yang mengefektifkan kinerja peralatan. Sistem ini juga akan mengintegrasikan sistem filterisasi guna meningkatkan kualitas air sehingga memenuhi standarisasi yang ditetapkan oleh Departemen Kesehatan Republik Indonesia. Adapun desain 
rancangan mekanisme penyediaan dan automasi penyediaan air bersih yang mencakup keempat elemen tersebut di atas dapat diperlihatkan pada Gambar 2 berikut ini.

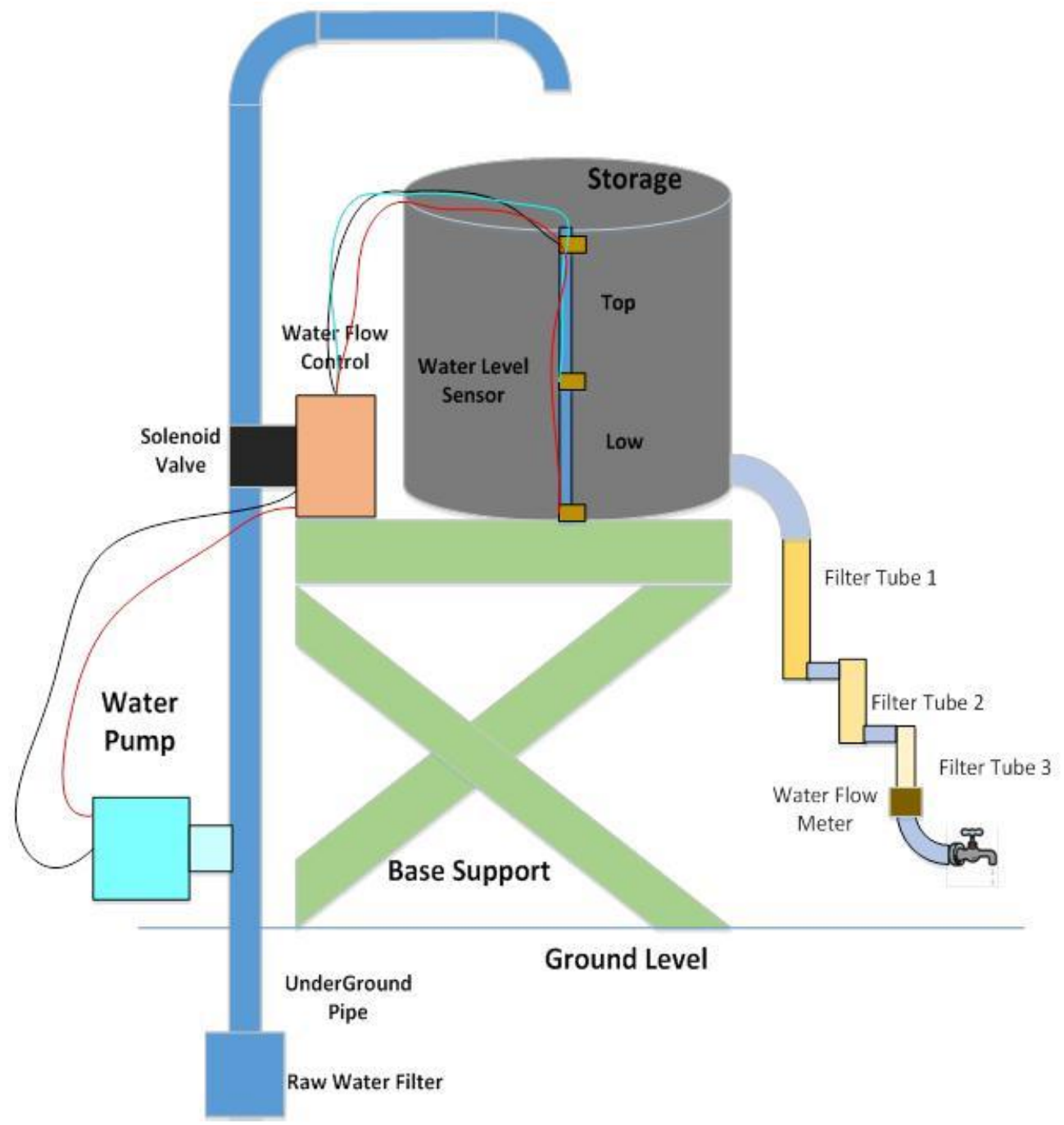

Gambar 2. Gambaran Umum Desain Penyediaan dan Automasi Sumber Air Bersih

Secara garis besar, mekanisme sistem ini dapat dibagi ke dalam lima elemen penting, yaitu:

1. Penyedia Air, dalam hal ini proses mengambil air tanah ke permukaan. Dalam proses ini dikembangkan bentuk sederhana penyediaan air dengan menggunakan air tanah yang diperoleh dari sumur galian. Mekanisme penggalian dengan metode horizintal drilling (Bair, E. S., 2009) pada lokasi yang telah ditetapkan dengan persetujuan dan arahan dari Kepala Desa Tellumpoccoe. Pipa berbahan PVC menjadi media penyaluran dari air bawah tanah ke permukaan dengan kemampuan mekanis dari mesin pompa elektrik.

2. Penyimpanan, dalam hal ini tangki penyimpanan air sementara. Tangki atau bak penyimpanan ini berada di atas permukaan tanah dengan sandaran dudukan bangunan konstruksi logam besi. Pengaturan volume air tersimpan terhubung langsung dengan proses aktivasi dari mesin pompa. 
3. Sistem Filterisasi, meliputi 3 tahapan filterisasi. Tahapan pertama dilakukan pada Tabung 1 yang bersisi kombinasi bahan-bahan batu zeolit, pasir silika, karbon aktif dan filter air, cartridge CTO filter carbon block. Proses filterisasi pada Tabung 1 dilakukan lagi pada Tabung 2, sedangkan pada Tabung 3 berisi filter air, cartridge CTO filter carbon block dan ultraviolet untuk proses sterilisasi air.

4. Penyaluran, yang meliputi mekanisme pengaturan dan perekaman penggunaan air yang nantinya dapat dimanfaatkan untuk pemeliharaan dan keberlangsungan fungsi dari sistem penyediaan air bersih secara umum. Water Flow Sensor digunakan dalam mendeteksi aliran debit air untuk proses pendataan penggunaan air. Sehingga nantinya data penggunaan air ini dapat dimanfaatkan untuk pengaturan swadana pembiayaan operasional dari keseluruhan sistem.

5. Automasi sistem yang menyangkut integrasi teknologi dalam proses kerja dari keseluruhan sistem. Keseluruhan mekanisme kendali dari sistem berbasis teknologi sistem tersemat (Embedded System) mengendalikan secara tersentralisasi (White, E., 2011). Deteksi permukaan air dalam bak penyimpanan menentukan volume air yang tersimpan dalam bak penyimpanan yang bekerja secara otomatis mengaktivasi kerja pompa air.

Bahan baku dari sistem filterisasi secara keseluruhan yang akan digunakan diperlihatkan pada Table 1 berikut ini dengan acuan pada (BPPT, 2016).

Tabel 1. Jenis Bahan Filterisasi

\begin{tabular}{|l|l|}
\hline No. & \multicolumn{1}{|c|}{ Jenis Bahan } \\
\hline 1. & Batu Zeolit \\
\hline 2. & Pasir Silika \\
\hline 3. & Karbonaktif \\
\hline 4. & Filter Air, cartridge CTO filter carbon block \\
\hline 5. & Pipa PVC \\
\hline 6. & Variasi Konektor Pipa \\
\hline 7. & Seal tip dan PVC Glue \\
\hline 8. & Water tap \\
\hline 9. & Ultraviolet Sterilisasi Air \\
\hline 10. & Control Unit \\
\hline 11. & Water Storage \\
\hline 12. & Raw Water Filter \\
\hline 13. & Water Pump \\
\hline 14. & Water Level Sensor \\
\hline 15. & Water Flow Sensor \\
\hline 16. & Base Concrete Construction \\
\hline & \\
\hline
\end{tabular}




\section{Target Capaian}

Kegiatan ini menargetkan pembuatan prototipe automasi dari sistem penyediaan air yang nantinya akan dikonstruksi secara fisik pada lahan yang strategis dan terjangkau oleh masyarakat yang membutuhkan pada Desa Tellompoccoe. Aspek kesehatan menjadi acuan dalam proses desain mekanisme filterisasi dan dalam menentukan kualitas luaran air nantinya (acuan pada Peraturan Menteri Kesehatan Republik Indonesia). Selain itu, aspek geologis yang meliputi aspek struktur air tanah yang mengandung kadar garam tinggi akan menjadi acuan pemilihan lokasi konstruksi. Aspek keterlangsungan juga menjadi bahan pertimbangan dalam rancang bangun dan konstruksi sistem, dimana mengingat taraf pendapatan masyarakat pada lokasi mitra yang berdampak langsung pada biaya operasional dan pemeliharaan. Aspek keberlangsungan ini diakomodir dengan integrasi mekanisme pencatatan aliran air sehingga masyarakat yang memanfaatkan sistem ini dapat membuat manajemen pembiayaan secara bersama. Selain itu, guna memenuhi aspek pemeliharaaan pada peralatan, tim pengabdian pada masyarakat nantinya akan menyediakan pelatihan terkait pemanfaatan dan operasional serta pemeliharaan teknis dari keseluruhan sistem. Tabel 2 berikut memperlihatkan aspek-aspek yang menjadi perhatian dan acuan untuk proses penanganan sekaligus tindak lanjut untuk pencapaian kegiatan.

Tabel 2. Aspek yang Menjadi Tolak Ukur dan Tindak Lanjut

\begin{tabular}{|c|c|c|c|c|}
\hline No. & Aspek Perhatian & Acuan & Tindak Lanjut & Target \\
\hline 1 & Kesehatan & \begin{tabular}{|l|} 
1. Peraturan Menteri Kesehatan Republik \\
Indonesia Nomor 429/Menkes/PER/IV/2010 \\
2. Keputusan Menteri Kesehatan Republik \\
Indonesia Nomor 1405/menkes/sk/xi/2002 \\
3. Badan Kesehatan Dunia (WHO) \\
\end{tabular} & \begin{tabular}{|l|} 
1. Survey Lokasi sebelum \\
penentuan Lokasi Konstruksi \\
2. Uji Sistem Filterisasi pada \\
hasil desain dengan mengukur \\
kualitas air luaran
\end{tabular} & $\begin{array}{l}\text { Memenuhi standarisasi air layak } \\
\text { konsumsi yang berlaku }\end{array}$ \\
\hline 2 & $\begin{array}{l}\text { Ekonomis \& } \\
\text { Keberlangsungan }\end{array}$ & $\begin{array}{l}\text { 1. Harga per KWH listrik PT. PLN Indonesia } \\
\text { 2. Konsumsi air per kepala keluarga }\end{array}$ & \begin{tabular}{|l|} 
1. Penyediaan mekanisme \\
pengukur aliran air \\
2. Koordinasi dengan mitra \\
penanggung jawab untuk \\
pelaksanaan pelatihan \\
penggunaan dan sekaligus \\
pemeliharaan dan perbaikan
\end{tabular} & $\begin{array}{l}\text { Pemanfaatan peralatan dapat terus } \\
\text { berkelanjutan dan kemandirian dalam } \\
\text { operasional dan perbaikan }\end{array}$ \\
\hline
\end{tabular}

\section{Implementasi Kegiatan}

Proses pelaksanaan kegiatan pengabdian nantinya akan melibatkan masyarakat setempat baik dalam proses perencanaan lokasi, proses konstruksi sampai pada proses operasional dan pemeliharaan. Kepala Desa Tellumpoccoe menyambut baik pelaksanaan kegiatan ini dengan memberikan bukti kesediaan berpartisipasi pada kegiatan pengabdian ini (Lampiran Bukti Kesediaan Bekerjasama). Kegiatan pada Tabel 3 di bawah ini memperlihatkan peran dan partisipasi dari mitra Desa Tellompuccoe dalam kegiatan pengabdian Penyediaan dan Automasi Sumber Air Bersih Umum. 
Tabel 3. Partisipasi dari Mitra Desa Tellompuccoe dan Tim dalam Kegiatan Pengabdian

\begin{tabular}{|c|c|c|c|c|c|}
\hline \multirow{3}{*}{ No } & \multirow{3}{*}{ Jenis Aktifitas } & \multicolumn{4}{|c|}{ Partisipasi } \\
\hline & & \multicolumn{2}{|r|}{ Tim Pengabdian } & \multicolumn{2}{|r|}{ Mitra Desa Tellompoccoe } \\
\hline & & Persentase & Jenis & Persentase & Jenis \\
\hline 1 & Survey Lokasi & $50 \%$ & Survey Bersama & $50 \%$ & Survey Bersama \\
\hline 2 & Transportasi peralatan dan bahan & $10 \%$ & Pendampingan & $90 \%$ & Tenaga Manusia \& Kendaraan \\
\hline 3 & $\begin{array}{l}\text { Konstruksi Pondasi dan Peletakan Bak } \\
\text { Penampungan }\end{array}$ & $10 \%$ & Pendampingan & $90 \%$ & Tenaga Manusia \\
\hline 4 & $\begin{array}{l}\text { Desain dan Rancang Bangun Sistem } \\
\text { Filterisasi }\end{array}$ & $100 \%$ & Prototiping & $0 \%$ & - \\
\hline 5 & $\begin{array}{l}\text { Desain dan Rancang Bangun Sistem } \\
\text { Automasi }\end{array}$ & $100 \%$ & Prototiping & $0 \%$ & - \\
\hline 6 & Simulasi Kinerja Sistem & $100 \%$ & Lab Testing & $0 \%$ & - \\
\hline 7 & Instalasi Sistem Pompa & $20 \%$ & Pendampingan & $80 \%$ & Tenaga Manusia \\
\hline 8 & Instalasi Automasi & $40 \%$ & Pendampingan \& Installasi Bersama & $60 \%$ & $\begin{array}{l}\text { Pendampingan, Installasi Bersama \& } \\
\text { Tenaga Manusia }\end{array}$ \\
\hline 9 & Uji Keseluruhan Sistem & $30 \%$ & Pendampingan \& Testing & $70 \%$ & Pembantu selama proses \\
\hline 10 & Finalisasi termasuk pengecatan & $5 \%$ & Pendampingan & $95 \%$ & Tenaga Manusia \& dana pengecatan \\
\hline 11 & Pelatihan operasional dan pemeliharaan & $60 \%$ & $\begin{array}{l}\text { Mengumpulkan data peserta dan } \\
\text { pemateri }\end{array}$ & $40 \%$ & Peserta dan Tempat pelatihan \\
\hline
\end{tabular}

\section{Hasil dan Diskusi}

Proses pelaksanaan kegiatan pengabdian nantinya melibatkan masyarakat setempat dari elemen masyarakat umum dan aparat desa. Sekitar 26 peserta latih mengikuti proses pelaksanaan kegiatan dengan tingkat penyerapan materi optimal melalui pengujian pelacakan kerusakan. Selain itu, data pendukung tingkat penyerapan materi juga diperoleh dari wawancara setelah kegiatan terkait materi pelatihan yang telah diberikan. Satu kelurga melaksanakan instalasi air bersih lebih jauh untuk konsumsi tingkat rumah tangga dan dari tim, diberikan pendampingan selama proses instalasi dan uji kelayakan konsumsi air hasil filterisasi. Selain itu, atas inisiatif masyarakat setempat, melalui koordinasi Kepala Desa Tellumpoccoe, tim teknis untuk air telah dibentuk yang beranggotakan ke-26 peserta latih tersebut.

\section{Kesimpulan}

Tingkat kesadaran dan pemahaman masyarakat semakin meningkat melalui antusiasme selama proses pelatihan. Luaran mampu mendorong 1 kepala keluarga untuk mengimplementasikan sistem filterisasi air bersih untuk kebutuhan rumah tangga (skala kecil). Diharapkan kedepannya masyarakat semakin antusias dalam turut menginstalasi filter air bersih untuk skala rumah tangga dan sekaligus mampu menjaga keberlangsungan dari pemanfaatan filter yang telah didesain tersebut.

\section{Ucapan Terima Kasih}

Ucapan terima kasih kepada Kepala Desa Tellumpoccoe dan jajaran staf desa yang telah memfasilitasi pelaksanaan kegiatana ini serta turut serta mendorong keaktifan masyarakat dalam kegiatan ini. Penghargaan yang setinggi-tingginya kepada Pemerintah Australia melalui hibah Australia Grant Scheme yang telah mampu mendukung terlaksananya kegiatan ini. Ucapan terima kasih kepada pihak Dinas Pemberdayaan Masyarakat Desa (PMD) Maros, Bupati Maros, dan Professor Juliet Willetts sebagai advisor dan expertise dalam kegiatan ini; dan instansiinstansi terkait lainnya, Perusahaan Daerah Air Minum Makassar, Balai Teknik Kesehatan Lingkungan dan Pengendalian Penyakit Makassar, Konsulat Jendral Australia di Makassar, 
Richard Matthews, dan kepada seluruh tim yang tergabung dalam riset group, Social, Cognitive Robotics and Advanced Artificial Intelligent Research Centre, Teknik Elektro UNHAS.

\section{Daftar Pustaka}

Badan Pusat Stratistik Maros (BPS Maros). (2015). Distribusi dan Kepadatan Penduduk, Jumlah Rumah Tangga Menurut Kecamatan di Kabupaten Maros. Terdapat pada laman https://maroskab.bps.go.id/linkTabelStatis/view/id/35\#accordion-daftar-subjek2. Diakses pada tanggal 15 Januari 2017.

Menteri Kesehatan Republik Indonesia (MENKES RI). (2010). Persyaratan Kualitas Air Minum. Peraturan Menteri Kesehatan Rebuplik Indonesia Nomor 492/Menkes/PER/IV/2010.

Bair, E. S. (2009), Groundwater and Wells, 3rd Edition. Ground Water, 47: 619. doi:10.1111/j.1745-6584.2009.00603. x.

White, E. (2011). Making Embedded Systems: Design Patterns for Great Software, O'Reilly Media, Incorporated.

Badan Pengkajian dan Penerapan Teknologi (BPPT). (2016). Cara Pengolahan Air Sumur Untuk Kebutuhan Air Minum. Terdapat pada laman http://www.kelair.bppt.go.id/Sitpa/Artikel/Akua/akua.html. Diakses pada tanggal 16 Januari 2017. 